\title{
Investigating the relationship between the perceived value of loyalty programs and customer citizenship behaviors Applied to customers' of mobile telecommunication companies in the Delta middle Sector
}

Dr. Prof.

Abdel-Hakeem A.Nagm

Professor of Business Management, faculty of commerce Mansoura University
Dr.Prof.

Mohamed A. EL-Hendawy

Professor of Marketing,

faculty of Commerce -

Damietta University
Mrs.

Sally M. Amer

Teaching Assistant

of Business Management, Faculty of Commerce -

Damietta University

\begin{abstract}
This study investigates how perceived value of loyalty programs stimulates customer citizenship behaviors (positive word of mouth, helping behaviors and constructive feedback) at mobile telecommunication companies in the Delta middle sector. Structural equation modeling (SEM) is employed to test the research hypotheses. Using data collected from 384 customers that participated in mobile telecommunication loyalty programs. The study concluded that there is a positive and significant relationship between perceived value of loyalty programs and customer citizenship behaviors. Furthermore, the theoretical and practical implications of the results are discussed along with the study's limitations and possible future research.
\end{abstract}

Keywords: Perceived Value of loyalty programs, Customer Citizenship Behaviors, Mobile Telecommunication Companies.

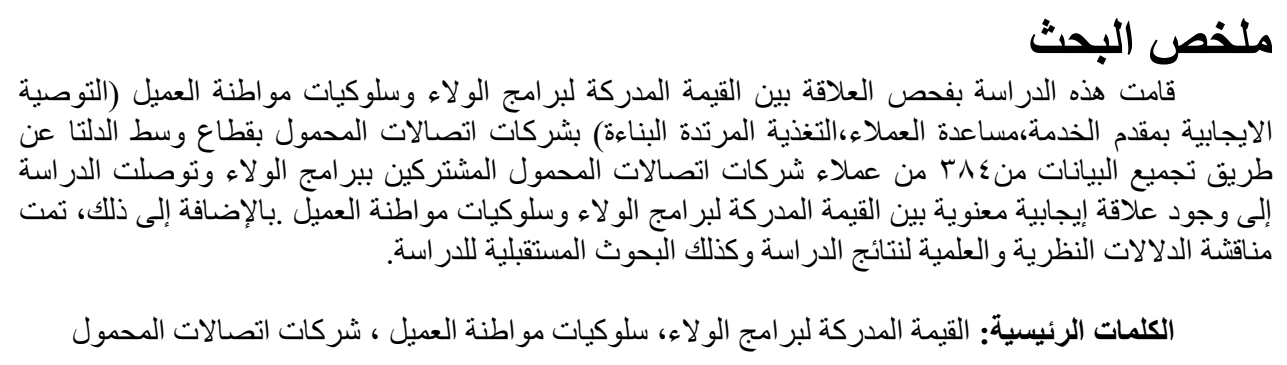




\section{1) Introduction}

Over the past decade, competition has significantly increased in the mobile telecommunications sector in Egypt, as a result customer loyalty and repurchase intentions become the most crucial and important factors for companies' survival and continuity in competition (Hilgeman, 2013).

Consequently, mobile telecommunication companies are seeking to attract and retain their customers. For attracting and retaining customers, companies aim to build customer loyalty by using loyalty programs. As customer loyalty programs have become one of the most necessary tools for companies for obtaining and increasing the number of true loyal customers (Kreis and Mafael, 2014) and have been recognized especially in the telecommunication industry in Egypt.

Additionally, as a result of service industry globalization and openness of international economy, Service companies put more interest in customer citizenship behaviors (CCBs) and this requires service companies to enhance their competitiveness continually. Therefore, in recent years the mobile telecommunication companies have paid more attention to customers in order to improve their competitiveness (Yang, 2011).

Previous studies showed that a well-designed loyalty programs have an excellent ability for attracting new customers, retaining current customers, encouraging customers by providing more support for their companies and decreasing the opportunity for switching to competitors' (Mimouni-Chaabane and Volle, 2010; Hilgeman, 2013; Khan, 2014).

Furthermore, previous studies have proposed that service organizations should view their customers as a valuable resource, not in terms of their inrole behaviors, but also in terms of their extra role as partial employees in improving company's performance(Yi and Gong, 2008; Bove et al., 2009; Fowler, 2013).

In service companies, customers are considered as "partial employees" and this participation is divided into in-role (customer participation) and/or extra-role behaviors (customer citizenship behaviors) (Fowler, 2013).

Despite of loyalty programs have been widely researched. The majority of the research focused on examining the effect of the perceived value of loyalty programs on; (the company's performance, the company's profits and brand equity) (Evanschitzky et al., 2012; Voorhees et al., 2015), but few studies focused on studying the impact of loyalty programs on customers (Mimouni-Chaabane and Volle, 2010). 
All previous studies explore the relationship between the perceived value of loyalty programs and customers citizenship behaviors are focused on studying customer citizenship behaviors through only one dimension either constructive feedback (Lacey, 2009), or helping behaviors (Choi and Kim, 2013) or positive word of mouth (Xie et al., 2011; Evanschitzky et al., 2012; Xie and chien, 2014; So et al., 2015).

So, there is no previous studies had examined the effect of the perceived value of loyalty programs on customer citizenship behaviors dimensions; (constructive feedback, helping behaviors and positive word of mouth).

In order to fill this gap, firstly, this study suggests one major research question as follows: What is the relationship between the perceived value of loyalty programs and customer citizenship behaviors?

Secondly, this study embraces the following objective: Testing the effect of perceived value of loyalty programs on customer citizenship behaviors (constructive feedback, helping behaviors and positive word of mouth.

\section{2) Literature Review}

\section{1) Loyalty Programs (LPs)}

Lo et al. (2017) defined Loyalty programs as "A defensive relationship marketing strategies that add value which is used by a company to reward its loyal customers by giving them free rewards, gifts and encouraging repeat purchases".

Some researchers argue that loyalty program is one of the most important sources for achieving company's competitive advantage by creating a great number of loyal customers.

These loyal customers have a great intention to pay a higher price than new customers, providing companies with useful ideas, providing positive referrals to their friends and family and refusing switch to other competitors' offers (Jones, 2009; Chi-Chang et al., 2014; Kandampully et al., 2015).

Moreover, Tanford (2013) and Wang et al. (2014) concluded that there is a positive correlation between customer participation levels (high- average - low) at loyalty programs and customers' perception of loyalty programs' benefits. 


\section{2) Perceived Value of Loyalty Programs}

This research depended on the following dimensions for measuring the perceived value of loyalty programs; (emotional value, symbolic value, functional value and economic value).

This research divided the literature review of the perceived value of loyalty into four sections. Firstly, emotional value. Secondly, symbolic value. Thirdly, functional value. Fourthly, economic value.

\subsection{1) Emotional Value:}

It refers to customers' feelings of happiness, joy and exciting when collecting and accumulating more points (Gyulavári, 2010; Terblanche, 2015; Voorhees et al., 2015).

Previous studies showed that customers' perception of emotional value has a positive impact on; program loyalty (Evanschitzky et al., 2012; Omar et al., 2012), program satisfaction (Evanschitzky et al., 2012; Kyguoliene et al., 2017), customers' perception of the relationship strength between company and customer through; self-connection and partner quality (Wang et al., 2014), spending more money (Share of Wallet). In addition, emotional value has a great impact on brand equity (Voorhees et al., 2015). However, there is no impact of emotional value on store loyalty (Chae-Suh and Yi, 2012). In addition, there is no impact of emotional value on trust in the program (Evanschitzky et al., 2012) .Moreover, Choi and Kim (2013) revealed that when customers' purchasing purpose is entertainment, so they prefer immediate rewards.

\subsection{2) Symbolic Value}

It refers to the ability of loyalty programs to offer a source of status, belongings, identification, recognition and special treatment. As a result, symbolic benefits are expressed through recognition and social benefits (Kyguoliene et al., 2017).

Previous studies showed that customers' perception of symbolic value has a positive impact on; program loyalty (Evanschitzky et al., 2012; Omar et al., 2012), program satisfaction (Evanschitzky et al., 2012; Kyguoliene et al., 2017), customers' perception of the relationship strength between company and customer through; self-connection and partner quality (Wang et al., 
2014). While, Evanschitzky et al. (2012) concluded that there is no relationship between symbolic benefit and trust in the program.

\subsection{3) Functional Value}

It refers to what degree the program is convenient to their customers and the loyalty programs' guidelines are easily understood by their participants (Xie and Chien, 2014).Previous studies concluded that there is a positive impact of functional value on; attitudinal and behavioral loyalty, relationship quality (trust, commitment, satisfaction) (Hilegman, 2013), purchase intensity, the resistance to competitors' programs and program loyalty (Xie and Chien, 2014), increasing customers' spending of money (Share of Wallet) . In addition, functional value has a great impact on brand equity (Voorhees et al., 2015).

While, Xie et al. (2011) revealed that there is an effect of functional value on switching costs. Additionally, Kyguoliene et al. (2017) showed that there is no effect of functional value on achieving customer satisfaction with the program.

\subsection{4) Economic Value}

It represents loyalty programs participants' feelings of financial advantages by obtaining monetary savings, reward redemption, and special offerings to loyalty programs participants'(Keris and Mafael, 2014). As monetary saving develops from cash back offers, discounts, and coupons that participants accumulated as a result, of buying the product from the same store or from a continuous and frequent purchase of a particular brand (Mimouni-Chaabane and Volle, 2010). In this study, the researchers focused on economic value, as it related to customers and the financial advantages they obtained by comparing between the cost and the benefit for obtaining the service. However, financial value related to the company's profits and revenues.

Previous studies concluded that there is a positive impact of economic value on; decreasing intention to switch to other competitors (Leenheer et al., 2007; Xie et al., 2011), program satisfaction (Omar et al., 2012; Omar et al., 2013; Kyguoliene et al., 2017), program loyalty(Omar et al., 2012; Omar et al., 2013),increasing customer loyalty (Pase et al., 2013), improving customers' perception of brand partner quality and brand selfconnection(Wang et al., 2014), increasing customers' spending (Share of Wallet), improving brand equity (Voorhees et al., 2015), program satisfaction (Kyguoliene et al., 2017). 


\section{This study used the preceding dimensions for the following reasons:}

1- Most of the previous studies depended on these dimensions (MimouniChaabane and Volle, 2010; Xie and Chien, 2011; Hilegman, 2013; Keris and Mafael, 2014; Xie and Chien, 2014).

2- These dimensions are very useful for marketers who are interested in evaluating the relationship between the company and their customers (Mimouni-Chaabane and Volle, 2010; Hilegman, 2013).

3- These dimensions contained all the value and benefits that participants obtained when they participate in loyalty programs (Mimouni-Chaabane and Volle, 2010; Keris and Mafael, 2014).

4- These dimensions focused on both financial and non-financial value and this will be useful in classifying customers according to their level of loyalty program usage (Mimouni-Chaabane and Volle, 2010; Xie and Chien, 2011; Xie and Chien, 2014).

5- These dimensions assist companies to identify the shortcomings of loyalty programs (Mimouni-Chaabane and Volle, 2010).

6- These dimensions support companies to create value (Mimouni-Chaabane and Volle, 2010).

\section{3) Customer Citizenship Behaviors (CCBs)}

Yi and Gong (2008); Yi et al., (2013) defined it as "A set of voluntary behaviors which have value for both customers and company, and these behaviors are not rewarded by the company procedures".

This research used the following dimensions for measuring customer citizenship behaviors; (positive word of mouth, helping behaviors, and constructive feedback).

\subsection{1) Positive word of mouth}

It is favorable, informal, person-to-person communication through recommending the firm or the employees to others; friends and relatives (Bove et al., 2009).

Previous studies have shown that positive word of mouth has positive impacts on the company as it is an indicator of customer loyalty, contributes to increase company reputation, more service quality perception and increases the number of customers (Bettencourt, 1997; Hansong et al., 2012). Also, it improves company's performance, decreases costs, increases sales 
and enhancing service quality (Fowler, 2013), increases company's growth and future sales (Eisingerich et al., 2014).

In addition, Jinfeng et al. (2014) revealed that corporate reputation significantly affects positive word of mouth. In order to gain customer citizenship behaviors, establishing the corporate reputation is an excellent way for companies. A company must focus not only on their competence, but also through providing their customers with superior value.

Li Lin et al. (2016) stated that the relationship between the prohibitive voice of service employee and CCBs customers citizenship behaviors; (constructive feedback, helping behaviors and positive word of mouth) through mediating procedural justice. As they defined prohibitive voice of service employee as customers' perception regarding how a service employee performs prohibitive voice such as; advice customers against undesirable behavior that would destroy service delivery. Moreover, clarify any undesirable behaviors customers might perform which lead to harm service delivery, telling customers about the recent and the future problems that they might face when dealing with the service and how to deal with it. Furthermore, they defined procedural justice as how service employee uses company's procedures to satisfy customers' needs. The study revealed that there is a positive impact of prohibitive voice on customer citizenship behaviors and procedural justice on customer citizenship behaviors. The study also indicated the success of prohibitive voice on a customer depends on the level of procedural justice being enhanced.

\subsection{2) Helping Behaviors}

It refers to the constructive efforts displayed by customers that aimed to help other customers (Anaza, 2014).

Previous studies put more emphasis on customer's motives for helping other customers and why other customers prefer helping their colleagues, friends and relatives more than service employees do. Rosenbaum and Massiah (2007) clarified that customers may show empathy toward other customers through helping behaviors. This may be due to customers' feelings of social responsibility of helping other customers who face difficulties. In addition, Soch and Aggarwal (2013) and Cruth et al. (2014) indicated that committed customers who have an emotional bond toward their company are motivated to help other customers. The study of Yi and Gong (2013) clarified the reasons why other customers prefer helping behaviors from their relatives, friends and colleagues rather than employees as other customers need help 
from customers who behave in a way that consistent with their beliefs, values and attitudes.

While, the study of (Jinfeng et al., 2014; Van et al., 2016) puts more consideration into the important role of corporate reputation in encouraging helping behaviors toward other customers and company. In addition, Van et al. (2016) showed that there is a positive effect of customer satisfaction, customer commitment and customer loyalty on encouraging customers' practicing helping behaviors toward other customers and the company.

\subsection{3) Constructive feedback}

It is providing ideas and suggestion that lead to the organization's improvement in the long-run (Groth, 2005).

The study of Bettencourt (1997) indicated why customers' ideas and suggestions are very necessary for their company? Customers are in a unique position to offer constructive ideas and suggestions to employees. Because customers have a good experience with the service that allow them to provide excellent suggestions as they can determine what customers' needs. While, Rosenbaum and Massiah (2007) proposed that there are two types of customer support toward other customers: social emotional support and instrumental support. The study also revealed that there is a positive impact of social emotional support and instrumental support on constructive feedback. Furthermore, Yi and Gong (2008) concluded that there is a positive relationship between positive effect such as; pleasurable engagement feelings of customers and constructive feedback. Bove et al. (2009) concluded that there is a positive role of service employee role; (commitment, credibility, benevolence) on increasing suggestions for service improvement.

In addition, Soch and Aggarwal (2013) and Cruth et al. (2014) revealed that committed customers who have a psychological attachment to their company are motivated to provide feedback; as a result committed customers indirectly improve service quality and service productivity. Moreover, the study of Xian et al. (2013) showed that there is a positive impact of good retail image on customers' providing useful and constructive feedback. Eisingerich et al. (2014) discovered that satisfied customers would be more motivated to provide constructive feedback.

\section{The researcher used the preceding dimensions for the following reasons:}

1- Most of the previous studies depended on these dimensions (Groth, 2005; Aanza and Zhao, 2013; Fowler, 2013; Soch and Aggarwal, 2013; Xian et al., 
2013; Yi et al., 2013; Yi and Gong, 2013; Balaji, 2014; Cruth, 2014; Eisingerich et al., 2014).

2- These dimensions are very useful for marketers who interested in maximizing customers citizenship behaviors (Fowler, 2013; Balaji, 2014; Cruth, 2014; Eisingerich et al., 2014).

\section{4) Conceptual framework}

After presenting the study's variables, the relationship among them will be clarified to build a conceptual framework (Figure 1) and matching hypotheses.

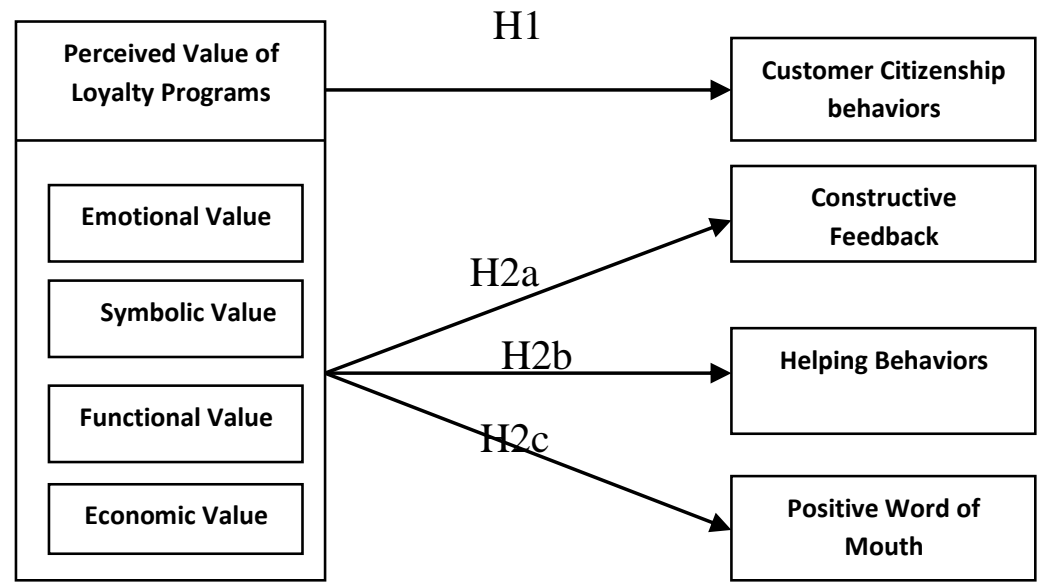

Figure1. Hypothesized model of the study

\section{5) Perceived Value of loyalty Programs and Customer Citizenship Behaviors}

According to the relationship exchange theory, the relationship between the related parties; (customer and company) are determined by the evaluation of the benefits and costs of the relationship. If customers receive high value of benefits at lower costs compared to competitors, they will be more committed to the relationship and this will create an obligation to the other party to reciprocate. Social exchange theory can be used to predict customer citizenship behaviors (Balaji, 2014). Therefore, parties involved in a social exchange will try to maintain, develop and improve their relationship (Anaza and Zhao, 2013). 
Choi and Kim (2013) concluded that Participants of loyalty programs practice more citizenship behaviors; (helping behaviors) than non-participants have. In addition, Xie and Chien (2014) revealed that there is a positive impact of the perceived value of loyalty programs on customers' practicing positive word of mouth. Also, there is a positive impact of participating in loyalty programs on customer's providing constructive feedback (Lacey, 2009).

While, Xie et al. (2011) revealed that there is no effect of the perceived value of loyalty programs; (psychological value, functional value and economic value) on providing positive word of mouth. The majority of previous studies on customer citizenship behaviors are considered citizenship behaviors as a general concept without differentiating constructive feedback, helping behaviors or positive word of mouth. The researchers revealed that no previous studies have examined the effect of perceived value of loyalty programs on all dimensions of CCBs together with each other (positive word of mouth, helping behaviors and constructive feedback) and this represents the main objective of the study.

The study proposes that perceived value of loyalty programs is positively related to customer citizenship behaviors. Thus, this study suggests the following hypotheses:

H1. There is a significant positive correlation between perceived value of loyalty programs and customer citizenship behaviors

$\mathrm{H} 2$ : There is a positive effect of Perceived value of loyalty programs; (emotional value, symbolic value, functional value and economic value) on customer citizenship behaviors.

\section{This hypothesis can be divided into the following sub-hypotheses:}

$\mathrm{H} 2 \mathrm{a}$ : There is a positive effect of Perceived value of loyalty programs; (emotional value, symbolic value, functional value and economic value) on constructive feedback.

$\mathrm{H} 2 \mathrm{~b}$ : There is a positive effect of Perceived value of loyalty programs; (emotional value, symbolic value, functional value and economic value) on helping behaviors.

$\mathrm{H} 2 \mathrm{c}$ : There is a positive effect of Perceived value of loyalty programs; (emotional value, symbolic value, functional value and economic value) on positive word of mouth. 


\section{3) Research Methods}

\section{1) Sample and Procedures}

The current research applied to mobile telecommunication companies, which are three companies (Vodafone, Orange and Etisalat). Due to the difficulty to reach all the population and other restrictions, including time and cost. As there is no population framework for customers who have participated in loyalty programs in the three telecommunication companies. The researchers used Quota Sampling as a procedure that restricts the selection of the sample by controlling the number of respondents by one or more criterion (Shukla, 2008, p.63). In this case, the restriction is according to the market share of the three mobile telecommunication companies in Egypt; (Vodafone, Orange, and Etislat) (See table 1).

Table1. Number of customers at mobile telecommunication companies, market share percentage, sample distribution and the number of respondents

\begin{tabular}{|c|c|c|c|c|c|}
\hline $\mathbf{N}$ & Company & $\begin{array}{c}\text { Numbers of } \\
\text { Customers* }\end{array}$ & $\begin{array}{c}\text { Market } \\
\text { Share } \\
\text { Percent }\end{array}$ & $\begin{array}{c}\text { Sample } \\
\text { Distribution }\end{array}$ & $\begin{array}{c}\text { Number of } \\
\text { Respondents }\end{array}$ \\
\hline 1 & Vodafone & 39.8 million & $41 \%$ & 157 & 127 \\
\hline 2 & Orange & 33.5 million & $34.6 \%$ & 133 & 120 \\
\hline 3 & Etisalat & 23.7 million & $24.4 \%$ & 94 & 50 \\
\hline & Total & 97.227 million & $100 \%$ & 384 & 297 \\
\hline
\end{tabular}

*Source: www.mcit.gov.eg.

\section{2) Sample Size:}

The sample size was determined at confidence level $95 \%$ and standard error 5\%. The sample size was calculated according to Malhotra equation (Malhotra, 2007, p.373) the sample size is 384 customers.

\section{3) Sampling Distribution:}

The questionnaires distributed in the four governorates, according to weighted ratio (the percentage of citizens in each governorate to the whole number of citizens in the 4 governorates) (See table 2).

Table2. Governorate Name, shows number of customers in each governorate, weighted ratios, sample size, number of respondents, and response rate

\begin{tabular}{|c|c|c|c|c|c|}
\hline $\begin{array}{c}\text { Governorate } \\
\text { Name }\end{array}$ & $\begin{array}{c}\text { No of citizens in } \\
\text { each } \\
\text { governorate* }\end{array}$ & $\begin{array}{c}\text { weighted } \\
\text { ratios }\end{array}$ & $\begin{array}{c}\text { sample } \\
\text { size }\end{array}$ & $\begin{array}{c}\text { number of } \\
\text { responden } \\
\text { ts }\end{array}$ & $\begin{array}{c}\text { respons } \\
\text { e rate }\end{array}$ \\
\hline El Dakahlia & 6122343 & $35.3 \%$ & 136 & 111 & $80.2 \%$ \\
\hline El-Gharbia & 4890664 & $28 \%$ & 108 & 93 & $86.1 \%$ \\
\hline El-Monefya & 4074051 & $23.5 \%$ & 90 & 56 & $62.2 \%$ \\
\hline Kafer-Elsheikh & 2277878 & $13 \%$ & 50 & 37 & $74 \%$ \\
\hline Total & 17364936 & $100 \%$ & 384 & 297 & $77.3 \%$ \\
\hline
\end{tabular}

*Report of Central Agency for Public Mobilization and Statistics, April 2016. 


\section{4) Measures}

All constructs were measured with a 5-point Likert type scale $(5=$ strongly agree, $4=$ agree, $3=$ neutral, $2=$ disagree, $1=$ strongly disagree).

\subsection{1) Perceived Value of loyalty Programs}

Perceived value of loyalty programs is assessed by using the previously validated scales of (Dowling and Uncles, 1997; Long and Schiffman, 2000; Sweeney and Soutar, 2001; Mimouni-Chabaane and Volle, 2010).

\subsection{2) Customer Citizenship behaviors}

Customer citizenship behaviors are measured by using the prior validated scales of (Bettencourt, 1997; Growth, 2005; Bove et al., 2009; Johnson and Rapp, 2010; Yi and Gong, 2013).

\section{4) Data Analysis: Model Assessment \\ 4.1) Introduction}

The study adopted various statistical techniques to investigate the study instrument's reliability and validity, in addition to test the research hypotheses. Data were analyzed using the computer program: Statistical Package for Social Science (SPSS V23). In addition, the Excel sheet for screening data and stats package tool for assessing composite reliability, convergent and discriminant validity. Techniques and tests were used:

- Cronbach's Alpha Coefficient: was used to test the internal consistency reliability of variables.

- Composite Reliability: was used to test the internal consistency reliability of variables.

- Correlation Matrix: was used to measure the relationship between two variables or more and for measuring relationship type and strength, and it uses for testing the first hypothesis.

- Multiple Stepwise Regression: was used to measure the relationship between the independent and dependent variables, and it uses for testing the second hypothesis.

\section{2) Measurement Model}

The aim of the first stage is to estimate the instruments' quality in terms of item factor loadings, internal consistency and discriminant validity. All constructs are reflectively evaluated only as first-order 
factors. Table (3) shows that factor loading of the items were well above the suggested threshold of 0.50 (Hair et al., 2010). Furthermore, Cronbach's alpha $(\alpha)$ and composite reliability (CR) for each of the constructs are greater than the suggested threshold of 0.70 . This reveals that the measures were reliable (Straub et al., 2004).Moreover, to estimate convergent validity, Fornell and Larcker (1981) proposed that average variance extracted (AVE) should be equal or greater than 0.50. Table (3) shows that AVE is above 0.50 for all constructs, so, this indicates adequate convergent validity.

Table3. Loadings, Cronbach's Alpha, Composite reliability and Average Variance Extracted

\begin{tabular}{|c|c|c|c|c|}
\hline Constructs, dimensions, and indicators & $\begin{array}{c}\text { Load } \\
\text { ings }\end{array}$ & $\mathbf{A}$ & CR & AVE \\
\hline \multicolumn{5}{|l|}{ Perceived Value of Loyalty Programs } \\
\hline \multicolumn{2}{|l|}{ Emotional Value (Emo) } & 0.722 & 0.678 & 0.515 \\
\hline $\begin{array}{l}\text { Emo1 I feel bad if I miss an opportunity to get } \\
\text { mileage points. }\end{array}$ & 0.761 & & & \\
\hline $\begin{array}{l}\text { Emo2 I feel good when I look at my statement } \\
\text { showing the number of mileage points earned. }\end{array}$ & 0.668 & & & \\
\hline \multicolumn{2}{|l|}{ Symbolic Value (Sym) } & 0.840 & 0.831 & 0.502 \\
\hline Sym1 Better recognition than non-members. & 0.725 & & & \\
\hline $\begin{array}{l}\text { Sym2 Special promotions available only to } \\
\text { members }\end{array}$ & 0.749 & & & \\
\hline $\begin{array}{l}\text { Sym3Through the loyalty program membership I can } \\
\text { express my appreciation for the company. }\end{array}$ & 0.626 & & & \\
\hline $\begin{array}{l}\text { Sym4 Give me a sense of belonging to a community of } \\
\text { people who share the same values. }\end{array}$ & 0.732 & & & \\
\hline Sym5I feel I share the same brand values. & 0.770 & & & \\
\hline Functional Value (Fun) & & 0.845 & 0.873 & 0.634 \\
\hline Fun1 Reasonable rewards for what I spend. & 0.877 & & & \\
\hline Fun2 Many reward options. & 0.822 & & & \\
\hline Fun3 Many reward redemption possibilities. & 0.808 & & & \\
\hline Fun4 Easy to achieve reward redemption. & 0.736 & & & \\
\hline Economic Value (Eco) & & 0.702 & 0.759 & 0.514 \\
\hline Eco1 Ability to obtain free coupons and gifts. & 0.797 & & & \\
\hline Eco2 I shop at lower financial cost. & 0.572 & & & \\
\hline $\begin{array}{l}\text { Eco3 Ability to combine mobile company points with } \\
\text { hotel points and airline miles. }\end{array}$ & 0.742 & & & \\
\hline \multicolumn{5}{|l|}{ Customer Citizenship Behavior } \\
\hline Constructive Feedback & & 0.832 & 0.854 & 0.540 \\
\hline $\begin{array}{l}\text { CF1 I call customer service to make suggestions to } \\
\text { improve this organization. }\end{array}$ & 0.738 & & & \\
\hline $\begin{array}{l}\text { CF2 I contact the organization via website or } \\
\text { salesperson when something occurs that affects their } \\
\text { business. }\end{array}$ & 0.752 & & & \\
\hline $\begin{array}{l}\text { CF3 I fill out customer satisfaction surveys for this } \\
\text { organization. }\end{array}$ & 0.784 & & & \\
\hline $\begin{array}{l}\text { CF4 I would do things that make the employee's job } \\
\text { easier. }\end{array}$ & 0.687 & & & \\
\hline
\end{tabular}




\begin{tabular}{|l|l|l|l|l|}
\hline $\begin{array}{l}\text { CF5I would let my...know of ways that...could better } \\
\text { serve } \\
\text { my needs }\end{array}$ & 0.756 & & & \\
\hline Helping Behaviors (HP) & 0.918 & 0.871 & 0.911 & 0.837 \\
\hline HP1 I teach other customers to use the service correctly. & 0.912 & & & \\
\hline $\begin{array}{l}\text { HP2 I help other customers if they seem to have } \\
\text { problems. }\end{array}$ & & 0.897 & 0.915 & 0.685 \\
\hline Positive Word of Mouth (+WOM) & 0.872 & & & \\
\hline +WOM1 I encouraged friends and relatives to use.... & & & \\
\hline $\begin{array}{l}\text { +WOM2 If I hear someone say something negative } \\
\text { about the organization, I will try to persuade him or her } \\
\text { to think otherwise. }\end{array}$ & 0.828 & & & \\
\hline +WOM3 I say positive things about the company. & 0.916 & & & \\
\hline +WOM4 I enjoy talking about this organization & 0.787 & & & \\
\hline $\begin{array}{l}\text { +WOM5I advice other customers to use company's } \\
\text { loyalty program. }\end{array}$ & 0.724 & & & \\
\hline
\end{tabular}

Table4. Construct Correlations and Square Root of Average Variance Extracted

\begin{tabular}{|c|c|c|c|c|c|c|r|}
\hline Construct & HB & Emo & Sym & Fun & Eco & CF & + +WOM \\
\hline Helping Behaviors(HB) & $\mathbf{0 . 9 1 5}$ & & & & & & \\
\hline Emotional (Emo) & 0.595 & $\mathbf{0 . 7 1 7}$ & & & & & \\
\hline Symbolic (Sym) & 0.461 & 0.614 & $\mathbf{0 . 7 0 9}$ & & & & \\
\hline Functional (Fun) & 0.330 & 0.420 & 0.380 & $\mathbf{0 . 7 9 6}$ & & & \\
\hline Economic (Eco) & 0.515 & 0.436 & 0.413 & 0.789 & $\mathbf{0 . 7 1 7}$ & & \\
\hline Constructive Feedback (CF) & 0.576 & 0.359 & 0.352 & 0.585 & 0.631 & $\mathbf{0 . 7 3 5}$ & \\
\hline Positive Word of Mouth (+WOM) & 0.672 & 0.461 & 0.525 & 0.435 & 0.511 & 0.662 & $\mathbf{0 . 8 2 8}$ \\
\hline
\end{tabular}

In support of discriminant validity, Table (4) reveals that the Square Root of the average variance extracted of each construct is greater than the inter-construct correlation, which confirms the discriminant validity of the latent constructs in the first-order measurement model except for economic value (Fronell and Larcker, 1981).

\section{3) Testing of Hypotheses}

\subsection{1) The correlation between perceived value of loyalty program and customer citizenship behaviors.}

H1: There is a significant positive correlation between perceived value of loyalty programs and customer citizenship behaviors. 
Table 5 .The Correlation Matrix between the dimensions of the study variables

\begin{tabular}{|c|c|c|c|c|c|c|c|c|c|}
\hline & Mean & S.D & Emo & Sym & Fun & Eco & CF & HB & +WOM \\
\hline Emotional & & & & & & & & & \\
\hline (Emo) & 3.88 . & .734 & 1 & & & & & & \\
\hline Symbolic & & & & & & & & & \\
\hline (Sym) & 3.25 & .801 & $0.614 * *$ & 1 & & & & & \\
\hline Functional & & & & & & & & & \\
\hline (Fun) & 3.85 & .740 & $0.420 * *$ & $.380^{* * *}$ & 1 & & & & \\
\hline Economic & & & & & & & & & \\
\hline (Eco) & 3.62 & .809 & 0.436 ** & $.413 * *$ & .789 ** & 1 & & & \\
\hline $\begin{array}{l}\text { Constructive } \\
\text { Feedback (CF) }\end{array}$ & 3.44 & .792 & $.359 * *$ & $.352 * *$ & $.585 * *$ & .631 ** & 1 & & \\
\hline $\begin{array}{l}\text { Helping Behaviors } \\
\text { (HB) }\end{array}$ & 3.77 & .960 & $.595 * *$ & .461 ** & $.330 * *$ & $.515 * *$ & $.576 * *$ & 1 & \\
\hline $\begin{array}{l}\text { Positive Word of } \\
\text { Mouth (+WOM) }\end{array}$ & 3.59 & .837 & $.461^{* * *}$ & $.525 * *$ & $.435 * *$ & $.511 * *$ & $.662 * *$ & $.672^{* * *}$ & 1 \\
\hline
\end{tabular}

**Correlation is significant at the 0.01 level (2-tailed).

\section{According to table (5):}

- The perceived value of loyalty programs emotional value scored highest with a mean (3.88) and a standard deviation 0.734 followed by the functional value mean (3.85) and a standard deviation 0.740, then economic value mean (3.62) and a standard deviation 0.809 and symbolic value mean (3.25) and a standard deviation 0.801 .

- Customers citizenship behaviors helping behaviors scored highest with a mean (3.77) and a standard deviation 0.960 followed by positive word of mouth mean (3.59) and a standard deviation 0.837 and constructive feedback mean (3.44) and a standard deviation 0.792 . 


\section{The relationship between emotional value and customers citizenship behaviors dimensions}

- There is a weak positive correlation between emotional value and constructive feedback as correlation coefficient value is 0.359 at significant level 0.01 .

- There is a strong positive correlation between emotional value and helping behavior as correlation coefficient value is 0.595 at significant level 0.01 .

- There is a medium positive correlation between emotional value and +WOM as correlation coefficient value is 0.461 at significant level 0.01 .

\section{The relationship between symbolic value and customers citizenship} behaviors dimensions

- There is a weak positive correlation between symbolic value and constructive feedback as correlation coefficient value is 0.352 at significant level 0.01 .

- There is a medium positive correlation between symbolic value and helping behaviors as correlation coefficient value is 0.461 at significant level 0.01 .

- There is a strong positive correlation between symbolic value and +WOM as correlation coefficient value is 0.525 at significant level 0.01 .

The relationship between functional value and customers citizenship behaviors dimensions

- There is a strong positive correlation between functional value and constructive feedback as correlation coefficient value is 0.585 at significant level 0.01 .

- There is a weak positive correlation between functional value and helping behaviors as correlation coefficient value is 0.330 at significant level 0.01 .

- There is a medium positive correlation between functional value and +WOM as correlation coefficient value is 0.435 at significant level 0.01 .

The relationship between economic value and customers citizenship behaviors dimensions:

- There is a strong positive correlation between economic value and constructive feedback as correlation coefficient value is 0.631 at significant level 0.01 .

- There is a strong positive correlation between economic value and helping behaviors as correlation coefficient value is 0.515 at significant level 0.01 .

- There is a strong positive correlation between economic value and +WOM as correlation coefficient value is 0.511 at significant level 0.01 . 
According to table (5), there is a significant positive correlation between perceived value of loyalty programs and customer citizenship behaviors. As a result, the first hypothesis is accepted.

\subsection{2) The effect of perceived value of loyalty programs on Customer Citizenship Behaviors}

H2: There is a positive effect of Perceived value of loyalty programs; (emotional value, symbolic value, functional value and economic value) on customer citizenship behaviors. This hypothesis is divided into the following sub-hypotheses:

$\mathrm{H} 2 \mathrm{a}$ : There is a positive effect of Perceived value of loyalty programs; (emotional value, symbolic value, functional value and economic value) on constructive feedback.

$\mathrm{H} 2 \mathrm{~b}$ : There is a positive effect of Perceived value of loyalty programs; (emotional value, symbolic value, functional value and economic value) on helping behaviors.

$\mathrm{H} 2 \mathrm{c}$ : There is a positive effect of Perceived value of loyalty programs; (emotional value, symbolic value, functional value and economic value) on positive word of mouth.

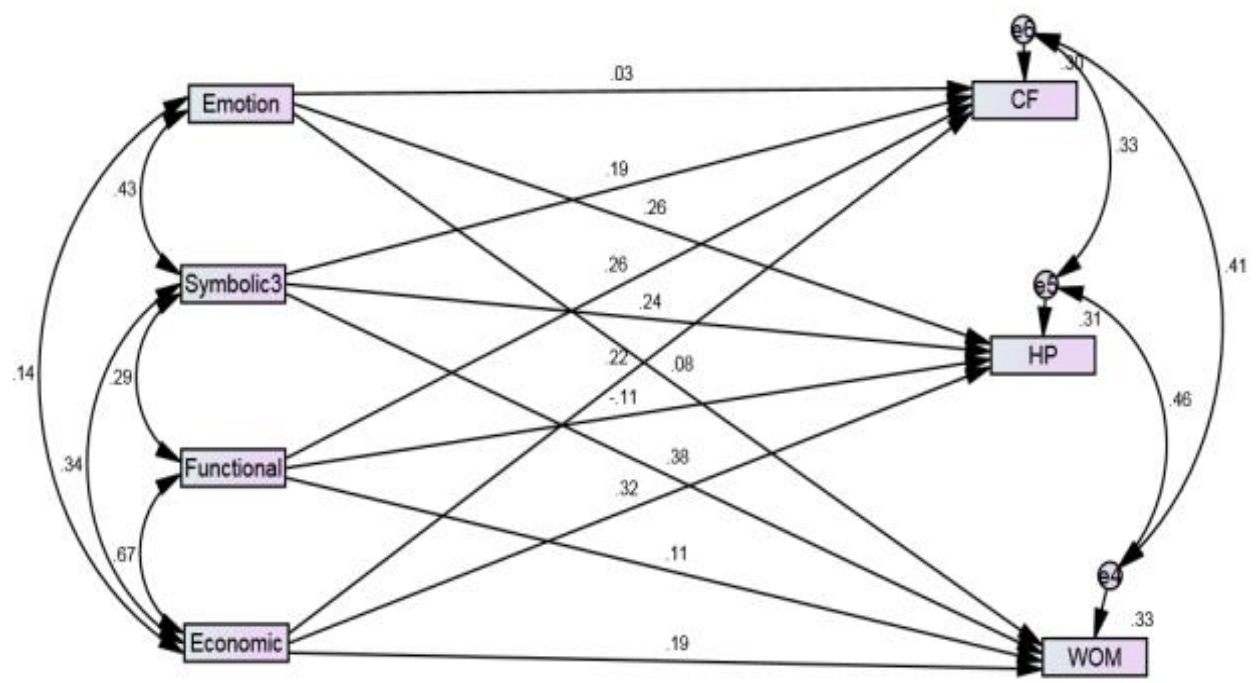

Figure (2) the effect of Perceived Value of Loyalty Programs on Customer Citizenship Behaviors. 
Table 6.The effect of perceived value of loyalty programs on CCBs

\begin{tabular}{|c|c|c|c|c|c|}
\hline Hypotheses & $\begin{array}{c}\text { Independent } \\
\text { Variables }\end{array}$ & $\begin{array}{c}\text { Dependent } \\
\text { Variable }\end{array}$ & Beta & P-Value & Decision \\
\hline \multirow{4}{*}{ H2a } & Emotional & \multirow{4}{*}{$\begin{array}{l}\text { Constructive } \\
\text { Feedback }\end{array}$} & 0.026 & 0.641 & Rejected \\
\hline & Symbolic & & 0.194 & $0.001 *$ & Accepted \\
\hline & Functional & & 0.255 & $0.001 *$ & Accepted \\
\hline & Economic & & 0.224 & $0.001 *$ & Accepted \\
\hline \multirow{4}{*}{ H2b } & Emotional & \multirow{4}{*}{$\begin{array}{l}\text { Helping } \\
\text { Behaviors }\end{array}$} & 0.259 & $0.001 *$ & Accepted \\
\hline & Symbolic & & 0.239 & $0.001 *$ & Accepted \\
\hline & Functional & & -0.111 & 0.099 & Rejected \\
\hline & Economic & & 0.322 & $0.001 *$ & Accepted \\
\hline \multirow{4}{*}{ H2c } & Emotional & \multirow{4}{*}{$\begin{array}{c}+ \text { Word of } \\
\text { Mouth }\end{array}$} & 0.076 & 0.158 & Rejected \\
\hline & Symbolic & & 0.379 & $0.001 *$ & Accepted \\
\hline & Functional & & 0.114 & 0.082 & Rejected \\
\hline & Economic & & 0.192 & $0.004 * *$ & Accepted \\
\hline
\end{tabular}

$* \mathbf{P} \leq \mathbf{0 . 0 1}, * * \mathbf{P} \leq \mathbf{0 . 0 5}$.

Notably, symbolic value, functional value and economic value significantly, positively and directly affect constructive feedback $(\beta=0.194$, $\mathrm{p}=0.001),(\beta=0.225, \mathrm{p}=0.001)$ and $(\beta=0.224, \mathrm{p}=0.001)$ respectively.

While, emotional value does not significantly affect constructive feedback $(\beta=0.026, p=0.641)$ (See Table 6). Therefore, $\mathrm{H} 2 \mathrm{a}$ is partially accepted.

The determination coefficient $\left(\mathrm{R}^{2}\right)$ equals $29.5 \%$, which means that the independent variables the perceived value of loyalty programs interpret $29.5 \%$ of the change in constructive feedback and the residual $70.5 \%$ due to other factors not taken into the model.

Emotional value, symbolic value and economic value significantly, and positively affect helping behaviors $(\beta=0.259, p=0.001),(\beta=0.239, p=0.001)$ and $(\beta=0.322, p=0.001)$ respectively. However, functional value does not affect helping behaviors $(\beta=-0.111, \mathrm{p}=0.099)$ (See Table 6). Therefore, H2b is partially accepted.

The determination coefficient $\left(\mathrm{R}^{2}\right)$ equals $30.5 \%$, which means that the independent variables the perceived value of loyalty programs interpret 
$30.5 \%$ of the change in helping behaviors and the residual $69.5 \%$ due to other factors not taken into the model.

In addition, symbolic value, functional value and economic value significantly and positively affect positive word of mouth $(\beta=0.379, p=0.001)$ and $(\beta=0.192, p=0.004)$ respectively.

While, emotional value and functional value do not significantly affect positive word of mouth $(\beta=0.076, p=0.158)$ and $(\beta=0.114, p=0.082)$ (See Table 6). Therefore, $\mathrm{H} 2 \mathrm{c}$ is partially accepted.

The determination coefficient $\left(\mathrm{R}^{2}\right)$ showed that the independent variables the perceived value of loyalty programs interpret $33.3 \%$ of the change in positive word of mouth and the residual $66.7 \%$ due to other factors not taken into the model.

\section{Based on the above results, the second hypothesis partially accepted.}

\section{5) Discussion}

This study investigated the association between perceived value of loyalty programs and customer citizenship behaviors (constructive feedback, helping behaviors and positive word of mouth). The study's results revealed that the perceived value of loyalty programs is significantly and positively related to customer citizenship behaviors (constructive feedback, helping behaviors and positive word of mouth) (H1, H2).

Interestingly, the study concluded that the perceived value of loyalty programs, in general, significantly influenced customers' citizenship behaviors. Notably, symbolic value, functional value and economic value significantly and positively affect constructive feedback $(\beta=0.194, p=0.001)$, $(\beta=0.225, p=0.001)$ and $(\beta=0.224, p=0.001)$ respectively.

While, emotional value does not significantly affect constructive feedback $(\beta=0.026, p=0.641)$. These results agree with (Lacey, 2009) that it showed that there is a positive impact of participating at loyalty programs on customer's providing constructive feedback. Furthermore, there is no impact of emotional value on customer's providing constructive feedback.

Moreover, emotional value, symbolic value and economic value significantly and positively affect helping behaviors $(\beta=0.259, \mathrm{p}=0.001)$, $(\beta=0.239, p=0.001)$ and $(\beta=0.322, p=0.001)$ respectively. While, functional value does not significantly affect helping behaviors $(\beta=-0.11, p=0.099)$. The 
study's result agrees with (Choi and Kim, 2013) that there is a positive effect of emotional value on customers' practicing helping behaviors. While the study's result disagrees with (Choi and Kim, 2013) that it showed that there is a positive effect of functional value on customers' practicing helping behaviors. However, the current study concluded that there is no effect of functional value on customers' practicing helping behaviors. In addition, symbolic value and economic value significantly and positively affect positive word of mouth $(\beta=0.379, \mathrm{p}=0.001)$ and $(\beta=0.192, \mathrm{p}=0.004)$ respectively.

However, emotional value and functional value do not significantly affect positive word of mouth $(\beta=0.076, p=0.158)$ and $(\beta=0.114, p=0.082)$ respectively. The study's results concluded that there is a positive relationship between loyalty programs and customer citizenship behaviors, and this result agrees with (Lacey, 2009; Anaza and Zhao, 2013; Choi and Kim, 2013; Balaji, 2014). The study's result agrees with (Xie et al., 2011; Xie and chien, 2014) that the study showed that there is no effect of the emotional value and functional value of loyalty programs on exercising positive word of mouth. While, the current study's result disagrees with (Xie et al., 2011; Xie and chien, 2014) that there is no effect of economic value on practicing positive word of mouth. In addition, the current study concluded that there is positive effect of the economic value on exercising positive word of mouth.

The current study's result agrees with (Xie and chien, 2014) that there is a positive effect of the symbolic value on exercising positive word of mouth.

Additionally, the current study's result agrees with (Evanschitzky et al., 2012) that there is a positive impact of symbolic and economic value on customers' practicing positive word of mouth. Furthermore, the current study's results agree with (So et al., 2015) that there is a positive impact of the economic value on customers' practicing positive word of mouth. In addition, there is no effect of functional value on customers practicing positive word of mouth. However, the result of the current study disagrees with (So et al., 2015) that the current study showed that there is no effect of emotional value on customers practicing positive word of mouth. However, (So et al., 2015) revealed that there is a positive effect of emotional value on customers practicing positive word of mouth.

It was concluded that when customers' feel happy and excited when they collected more points and having fun for redeeming collected points. 
So, this encourages customers foster more citizenship behaviors through helping other customers by telling other customers how to use the new service of LPs and how to enroll in LPs. When customers make a lot of calls and sending more messages as a result, this will increase customers' experience that enables them for helping other customers. Therefore, emotional value significantly affects helping behaviors. However, the study revealed that emotional value has an insignificant effect on both constructive feedback and positive word of mouth. As the process of getting more points depends on customers' usage of the company services that the customer is the only party who is responsible for collecting more points. As a result, customers do not provide useful ideas and information that help their companies for improving their ability to introduce better loyalty programs service. Customers do not provide positive referrals to their friends, relatives about the company and its LPs.

The current study revealed that when the company loyalty programs' focus more on how to make customers feel they belong to the group that share the same values and sharing company's value and also, feeling they are treated better than non-participants. As a result, they will exert more voluntary behaviors such as; providing constructive ideas and suggestions, helping other customers and providing positive word of mouth about the company and the LPs.

Functional value has a significant effect on customers' practicing constructive feedback. However, functional value does not significantly affect both helping behaviors and positive word of mouth. This may be due to the deficiency of the provided functional value that customers not easily understand the provided LPs; there is a little variation of alternative options for reward redemption, difficulty to achieve reward redemption. As a result, thus, may foster customers for providing more feedback that is constructive. So, this may have a positive impact on the company's performance, improving the rules and procedures for enrolling in LPs and how to redeem rewards easily.

While, the customer does not provide help for other customers about how to use the new LPs service as there is an ambiguity in understanding the rules and procedures. So, lack of understanding about how to deal with LPs makes most of the customers call customers service and asking it about any inquiry. Also, the difficulties of LPs procedures make customers provide negative referrals about the company and its LPs to their friends, colleagues and relatives. 
Considering the economic value when the company loyalty programs' put more attention to how to create more monetary advantages for participants through giving free gifts, rewards and saving money through discounts. This would have a positive impact on customers practicing more voluntary behaviors such as providing constructive ideas, helping other customers about how to use company loyalty program's and providing positive referrals to friends, relatives and to classmates.

\section{1) Theoretical and practical implications}

This study makes several essential contributions. First, this study seeks to fill the knowledge gap concerning the link between perceived value of loyalty programs and customer citizenship behaviors. It provides a detailed analysis of the effects of perceived value of loyalty programs on customer citizenship behaviors (constructive feedback, helping behaviors and positive word of mouth). Second, this study shows the way of how perceived value of loyalty programs affects customer citizenship behaviors (constructive feedback, helping behaviors and positive word of mouth).

The majority of previous studies on customer citizenship behaviors are considered citizenship behaviors as a general concept without differentiating constructive feedback, helping behaviors or positive word of mouth. All previous studies explore the relationship between the perceived value of loyalty programs and customers citizenship behaviors focused on studying CCBs through only one dimension either constructive feedback (Lacey, 2009), or helping behaviors (Choi and Kim, 2013) or positive word of mouth (Xie et al., 2011;Evanschitzky et al., 2012; Xie and chien, 2014; So et al., 2015).

However, other prior studies focused on studying CCBs as a general concept without differentiating CCBs dimensions (Anaza and Zhao, 2013; Balaji, 2014). This study contributes to the CCBs literature by concentrating more on the three dimensions of CCBs and how perceived value of loyalty programs affects it. The results put new insights to explain how customers' constructive feedback, helping behaviors and positive word of mouth are impacted in response to the perceived value of loyalty programs.

This study provides new insight into managerial guidance that managers should acknowledge about the role of the perceived value of LPs in developing CCBs. So, relationship marketers should explore these new trends into loyalty programs when managing customer relationships. This study's results showed that loyalty programs are marketing tools companies used to encourage loyal behaviors. 
This study revealed that the potential of leveraging loyalty programs is to build customers citizenship behaviors through several suggestions for practical implications. First, managers who focused on customer relationship management should design programs that meet their customers' needs and wants through making a balance between the cost, the time, the effort needed for enrolling in loyalty programs and the value proposition of loyalty programs, the perceived value. In addition, Companies can achieve Competitive advantage by clarifying the guidelines and the rules of enrolling in LPs in an easy way. Furthermore, companies should provide LPs that provide many reward redemption alternatives, more possible ways for points' redemption. When companies provide more distinct program that will increase switching cost. As a result, customers will not switch to other competitors', as they will lose the accumulated points and the opportunity for obtaining free rewards. Second, companies should provide highly valuable loyalty programs to their participants. When the company adds new options in its loyalty programs, company should perform a good advertising campaign for giving customer new offers. Also, customer service centers should answer all participants' inquiries. Third, companies should know how participants evaluate the way of interaction with company by appointing the customer experience manager.

As the customer experience manager should cooperate with the customer complaint manager. Besides, marketing managers should find an effective way of capturing feedback from participants of LPs for understanding the nature of their experience. This may be through designing customer survey, observational studies, voice of the customer research periodically for assessing LPs quality and trying to know how participants perceive the value of LPs, how to reinforce the advantages and to solve the defects?. Once companies collect information about customer experience, information needs to be disseminated to the managers of customers' complaints in a timely and relevant way.

As the degree of successful information, depend on getting the right information to the right people at the right time. Fourth, marketing managers should allow a strategy that focuses on proactive customer care rather than reactive in waiting for a customer complaint. Fifth, marketing managers should design the excellent way of communication methods. This leads to creating customer advocates and co-creator of value.

Additional practical implication relates to customer citizenship behaviors. Customers' citizenship behaviors in the mobile telecommunication companies can be enhanced by the following recommendations. Marketing managers should deliver formal thank to customers that practice positive and 
voluntary behaviors as this may make a significant difference in customers' minds. Furthermore, introducing customers who perform citizenship behavior for a customer group may create more citizenship behaviors.

\section{2) Limitations and future research}

The current study has some limitations that point to the future research directions. First, there were sampling limitations. Only the Delta middle sector was chosen as the geographical population frame, which limited the data collected to specific regions in Egypt. This may be due to the constraints of cost, time and effort. So, future studies can be applied in other regions in Egypt. Second, the current study does not examine the effect of individual cultural character, personality traits and industrial characteristics in the relationship between perceived value of LPs and CCBs. Therefore, future research may explore the effect of these potential moderators. Third, the current study used non-probability sample (quota sample) as there is no population framework for customers who have participated in loyalty programs in the three mobile telecommunication companies. So, future studies can be applied in other application fields that have a population framework to able to generalize the study' results. Fourth, this study tested the study's hypotheses with a questionnaire that provided only cross sectional data. Therefore, future research can develop a longitudinal to address methodological limitations. 


\section{References}

Anaza, N.A. (2014). Personality Antecedents of Customer Citizenship Behaviors in Online Shopping Situations. Journal of Psychology and Marketing, 31(4), 251-263.

Aanza, N. A. and Zhao, J. (2013).Encounter-based antecedents of e-customer citizenship behaviors. Journal of Services Marketing, 27 (2), 130-140.

Balaji, M.S. (2014). Managing customer citizenship behavior: a relationship perspective. Journal of Strategic Marketing, 22 (3), 222-239.

Bettencourt, L. (1997). Customer Voluntary Performance: Customers As Partner In Service Delivery. Journal of Retailing, 3,383 -406.

Bove, L., Pervan, S., Beatty, S. and Shiu, E. (2009). Service worker role in encouraging customer organizational citizenship behaviors. Journal of Business Research, 62, 698-705.

Chae-Suh, J. and Yi, Y. (2012). Do Consumption Goals Matter? The Effects of Online Loyalty Programs in the Satisfaction-Loyalty Relation. Psychology and Marketing, 29 (8), 549-557.

Chi-Chang, S., Rong-Faung, S., Ming-Huang, S., Chi-Chang, S. and Rong-Fang, S. (2014). The impact of relational bonds on brand loyalty: the mediating effect of brand relationship quality. Managing Service Quality, 24(2), 184204.

Choi, S. and Kim, S. (2013). Effects of a reward program on inducing desirable customer behaviors: The role of purchase purpose, reward type and reward redemption timing. International Journal of Hospitality Management, 32, 237-244.

Curth, S., Uhrich, S. and Benkenstein, M. (2014). How commitment to fellow customers affects the customer-firm relationship and customer citizenship behavior. Journal of Services Marketing, 28 (2), 147-158.

Dowling, G., R. and Uncles, M. (1997). Do Customer Loyalty Programs Really Work?.Sloan Management Review, 38 (4), 71-82.

Eisingerich, A., Auh, S. and Merlo, O. (2014). ActaNonVerba? The Role of Customer Participation and Word of Mouth in the Relationship between Service Firms' Customer Satisfaction and Sales Performance. Journal of Service Research, 17 (1), 40-53. 
Fornell, C. and Larcker, D. F. (1981). Evaluating structural equation models with unobservable and measurement errors. Journal of Marketing Research, 18 (1), 39-50.

Fowler, G. (2013). Customer Citizenship Behavior: An Expanded Theoretical Understanding. International Journal of Business and Social Science, 4 (5), $1-8$.

Groth, M. (2005). Customers as good soldiers: examining citizenship behaviors in internetservice deliveries. Journal of management, 31(1), 7-27.

Gyulavári, T. (2010). The effects of experience in loyalty card adoption on the importance of the attributes of loyalty schemes. Paper presented at 1 st EMAC Regional Conference on Marketing Theory Challenges in Emerging Societies Budapest, Hungary, 24-25.

Hair, J.F., Black, W.C., Babin, B.J., Anderson, R.E. and Tatham, R.L. (2010). Multivariate data analysis $\left(7^{\text {th }}\right.$ Eds.).New York: Pearson.

Hansong, Y., Keyil, W., Dan, Y. and Rong, L. (2012). The influences of customer citizenship behaviors on brand reputation. International Conference on Information Management, Innovation Management and Industrial Engineering, 393-396.

Hilgeman, D. (2013). Understanding the relationships between loyalty program rewards and loyalty among premium customers. Doctoral dissertation, Cypress, California University.

Jinfeng, L., Runtian, J. and Qian, C. (2014). Antecedents of Corporate Reputation and Customer Citizenship Behavior: Evidence from China. International Business and Management, 9 (1), 128-132.

Johnson, J. and Rapp, A. (2010). A more comprehensive understanding and measure of customer helping behavior. Journal of Business Research, 63, 787-792.

Jones, O. (2009). Pricing Strategies and Customer Loyalty Programmesin the Liberalised Book Market. Bachelor of Science in Business Administration, University of Applied Science Northwestern Switzerland.

Kandampully, J., Zhang, T. and Bilgihan, A. (2015). Customer loyalty: a review and future directions with a special focus on the hospitality industry. International Journal of Contemporary Hospitality Management, 27 (3), 379 - 414. 
Khan, M. (2014). Customer Loyalty Programs-Concept, Types, Goals and Benefits. International Journal of Information, Business and Management, $6(1), 74-93$.

Kreis, H. andMafael, A. (2014). The influence of customer loyalty program design on the relationship between customer motives and value perception. Journal of Retailing and Consumer Services, 21, 590-600.

Kyguoliene, A., Zikiene, k. and Grigaliunaite, V. (2017). The Influence of Perceived Benefits on The Satisfaction with the Loyalty Program. Journal of Inzinerine Ekonomika-Engineering Economics, 28(1), 101-109.

Lacey, R. (2009). Limited influence of loyalty program membership on relational outcomes. Journal of Consumer Marketing, 26 (6), 392-402.

Leenheer, J., Heerde, H., Bijmolt, T. and Smidts, A. (2007). Do Loyalty Programs Really Enhance Behavioral Loyalty? An Empirical Analysis Accounting for Self-Selecting Members. International Journal of Research in Marketing, 24, 31- 47.

Li Lin, Y., Wen Liu, H. and Thi Ngo, P. (2016). Silence Is not Golden: The Effects of Prohibitive Voice on Customer Citizenship Behaviors. International Business Research, 9 (9), 24-33.

Lo, A., Im, H.H., Chen, Y. and Qu, H. (2017) .Building brand relationship quality among hotel loyalty program members. International Journal of Contemporary Hospitality Management, 29 (1), 458-488.

Long, M. and Schiffman, L. (2000).Consumption values and relationships: Segmenting the market for frequency programs.Journal of Consumer Research, 17 (3), 214-228.

Malhotra, N. K. (2007). Marketing Research: An Applied Orientation (5 $5^{\text {th }}$ Eds.). New Jersey: Prentice Hall.

Mimouni-Chaabane, M. and Volle, P. (2010). Perceived benefits of loyalty programs: Scale development and implications for relational strategies. Journal of Business Research, 63, 32-37.

Omar, N., Wel, C., Abd Aziz, N. and Alam, S. (2013). Investigating the structural relationship between loyalty programme service quality, satisfaction and loyalty for retail loyalty programmes: evidence from Malaysia. Journal of Measuring Business Excellence, 17 (1), 33-50. 
Omar, N., Musa, R., Wel, C. and Abd Aziz, N. (2012). Examining the Moderating Effects of Programme Membership Duration in the Retail Loyalty Programme: A Multi Groups Causal Analysis Approach. World Applied Sciences Journal, 19 (3), 314-323.

Pase, P., Chung, N. and Cheol, S. (2013). Do reward programs build loyalty to restaurants? The moderating effect of long-term orientation on the timing and types of rewards. Managing Service Quality Journal, 23 (3), 225-244.

Rosenbaum, M. and Massiah, C. (2007). When Customers Receive Support From Other Customers Exploring the Influence of Inter customer Social Support on Customer Voluntary Performance. Journal of Service Research, 9 (3), 257-270.

Shukla, P. (2008). Marketing Research. Ventus Publishing APS.

So, J.T., Danaher, T. and Gupta, S. (2015). What do customers get and give in return for loyalty program membership?.Australasian Marketing Journal, 23, 196-206.

Soch, H. and Aggarwal, N. (2013). Influence of Commitment on Customer Discretionary Behaviour: A Survey in Retail Sector. Universal Journal of Management, 1 (2), 103-110.

Straub, D., Boudreau, M. C and Gefen. D. (2004) .Validation Guidelines For IS Positivit Research. The Communication of the Associations for Information Systems, 13(1), 380-427.

Sweeney, J.C. and Soutar, G.N. (2001). Consumer perceived value: the development of a multiple item scale.Journal of Retailing, 77 (2), 203-220.

Tanford, S. (2013). The impact of tier level on attitudinal and behavioral loyalty of hotel reward program members. International Journal of Hospitality Management, 34, 285-294.

Terblanche, N.C. (2015). Customers' Perceived Benefits of a Frequent-Flyer Program. Journal of Travel and Tourism Marketing, 32 (3), 199-210.

Van, N.T., Chi,T.T., Chi, V. and Quang, N.V. (2016). The Relationship between Customer-Based Corporate Reputation and Customer Citizenship Behavior: The Case in Vietnam. International Journal of Business and Management, 11 (9), 298-309.

Voorhees, C., White, R., McCall, M. and Randhawa, P. (2015). Fool's Gold? Assessing the Impact of the Value of Airline Loyalty Programs on Brand 
Equity Perceptions and Share of Wallet. Cornell Hospitality Quarterly, 56 (2), 202-212.

Wang, E., Chen, L. and Chen, F. (2014) .The antecedents and influences of airline loyalty programs: the moderating role of involvement. Journal of Revenue and Pricing, Management, 2 (3), 271-279.

Xian, H.,Quan, Z. and Fei, Z. (2013). An Empirical Study on the Impacts of Retail Agglomeration Image on Customer Citizenship Behavior. International Conference on Management Science \& Engineering, 903-908.

Xie, K., Xiong, L., Chien Chen, C. and Hu, C. (2011). Understanding Active Loyalty in Hotel Reward Programs through Customers' Switching Costs and Perceived Program Value. International CHRIE Conference-Refereed Track, $1-22$.

Xie, L. and Chien, C. (2014). Hotel loyalty programs: how valuable is valuable enough?.International Journal of Contemporary Hospitality Management, $26(1), 107-129$.

Yang, S. (2011). Review of the Measurement to Customer Citizenship Behaviors. School of Economic and Management, Shenyang Ligong University, Article in process.

Yi, Y. and Gong, T. (2008). The effects of customer justice perception and affect on customer citizenship behavior and customer dysfunctional behavior. Industrial Marketing Management, 37, 767-783.

Yi, Y. and Gong, T. (2013). Customer value co-creation behavior: Scale development and validation. Journal of Business Research, 66, 1279-1284.

Yi, Y., Gong, T. and Lee, H. (2013). The Impact of Other Customers on Customer Citizenship Behavior. Psychology and Marketing, 30 (4), 341-356.

\section{Websites}

www.mcit.gov.eg Egyptian Ministry of communication and Information Technology, October 2016.

Report of Central Agency for Public Mobilization and Statistics, April 2016. 